\section{Corruption in Romania}

Silviu DUȚULESCU, Bucharest University of Economic Studies,

E-mail: silviudemetrius@yahoo.com

Ileana NIŞULESCU-ASHRAFZADEH, Bucharest University of Economic Studies,

E-mail: ileana.nisulescu@cig.ase.ro

\section{Alostract}

Corruption as a phenomenon is of great interest for the society we live in. As there is no unit of measurement to determine the scale of this phenomenon, comparative studies are chosen most often for the areas concerned. The present paper describes a study focused on all counties in Romania, Bucharest included. The purpose of this research is to establish the determinant factors that influence the size and spread of corruption, as it manifests strong negative effects on the society we live in. Thus, using a set of regressions over the main variables, some correlation coefficients have been set, which after processing rendered a ranking of all the 42 analysed territorial units, sorted by the estimated size of corruption. The whole scientific approach was completed with a map of corruption, which synthesizes and presents the corruption spread nationwide.

Keywords: Corruption, county charts, corruption map, Romania.

JEL Classification: C40, D12, 012.

\section{To cite this article:}

Duțulescu, S. and Nişulescu-Ashrafzadeh, I. (2016),

Corruption in Romania, Audit Financiar, vol. XIV,

no. $6(138) / 2016$, pp. $680-687$,

DOI: 10.20869/AUDITF/2016/138/680

To link to this article:

http://dx.doi.org/10.20869/AUDITF/2016/138/680 


\section{Introduction}

Corruption is a complex phenomenon that takes place on many levels. It is a phenomenon encountered all over the world nowadays, from the most developed countries, to the poorest ones, having as a common denominator the violation of the "social rules". Unfortunately, corruption has negative long-term effects, which may prove to be even more harmful than a short war.

The literature in the field encloses many studies that focus on the negative effects of corruption, effects that can have a huge impact on the economic potential of a country and, thus, may induce the suffering of the entire population. Graeff and Svendsen (2012) show how corruption significantly decreases resource allocation, thus lowering labour productivity. A similar study by $\mathrm{Li}$ and Zahra (2012) shows how corruption in the political area discourages investors of good faith to be active on such a market, where the success of a business is based on its relationships with the governmental representatives and not on the level it answers market requirements. In such a situation, investors do not have an incentive to innovate, or to engage in productive activities, as their only purpose will be to keep as good relations as possible with the state representatives.

Corruption can leave a strong mark on both foreign trade and on attracting foreign investment, which is one of the main "engines" of the economy in the case of Romania. Kaditi (2013) explained that investors from countries with reduced rates of corruption (e.g. Scandinavia), do not make massive investments in countries where corruption is rated at high levels. In support of this theory, Zelekha and Sharabi (2012) show the contagious nature of this phenomenon. Thus, when a state with a high level of corruption has partnerships or economic relations with trading partners in a state far less corrupt, they tend to corrupt trading partners, thereby at least two national economies being affected. Preda (2015) has the same approach on corruption, pointing out that corruption affects the state both economically and functionally, by altering its morphological structure and creating a general feeling of instability that may extend easily into the neighbouring countries, especially to the trade partners with which the corrupted country has stronger economic relations. According to Dang (2009), the economic dimension of corruption can be seen as a hidden tax which contributes to the investor's costs and creates a climate of uncertainty over his entrepreneurial activity. This happens because this "tax" is not predictable, and at any moment it can turn a profitable economic entity into a bankrupt one. For these reasons, one of the determinants of a favourable business environment is the ability to interact with representatives of the state, without having to conduct "informal payments" (Krkoska and Robeck, 2008).

According to Marinescu and Jora (2013), corruption may have at least two dimensions. The first is defensive corruption, which is a reflex to protect citizens against the attempts of the civil servants, which use the levers of political power in order to try to steal some of their legitimate property. Specifically, the citizens resort to various workarounds beyond the border of legality, to pay less to the state. The second dimension is the offensive corruption, which involves "buying" senior civil servants to obtain various benefits. Diaconu (2012) discusses the corruption risk management, which involves a process that identifies institutional and individual factors that may favour the development of corruption. Corruption risk management also involves the development of some measures designed to prevent or eliminate the likelihood of corruption in a given area. In the vision of Beşliu (2015), the large number of interdependencies between countries of the world and the race for economic and political supremacy, as well as the purpose of more and more countries to get richer as soon as possible, tend to generalize. In this context it is almost mandatory to follow the size and development potential of corruption.

\section{Research methodology}

This research is motivated by the heterogeneous nature of economic development in different regions of Romania. It is known that the capital area formed a pole of economic development. Even if the Western area of the country has managed to maintain a reasonable level of economic development, in Moldavia, with few exceptions, the economic situation is precarious. Thus, it was followed if corruption presents a dispersion which may prove similar to the level of development of different areas of the country. For this purpose, information was collected about each of the 41 counties, Bucharest being also added, even if the capital involves certain specific features. To sum up, there are 42 territorial units that will be subject to detailed analysis in order to accurately determine the size and spread of corruption in each area. The main variable employed for this endeavour is the share of the corrupt people in the population total, information which was provided by the Academic Society of Romania and Romaniacurata.ro, which disclosed to all the interested people information concerning the activity of the National Anticorruption 
Department. Thus, for each county, including Bucharest, the percentage of people who have been convicted for corruption (divided by 10,000 residents) was assessed. This variable was be correlated with other four independent variables:

- The average net salary for 2014, which due to the large variations between counties was expressed as a percentage relating to the national average wage for 2014;

- The share of people with higher education in the total population, analysed for each territorial unit in 2014;

- The share of European funds absorbed by each territorial unit under review, in 2014;

- The average number of years spent in prison by a person convicted of corruption.

As further sources of information there were also used the gandul.info databases and analyses, and a set of databases provided by the National Institute of Statistics. In order to determine the influence of each independent variable on the percentage of persons who have been convicted for corruption, four regressions were be run using the software application Excel (Microsoft Office) and based on the recorded values of $R$-square, it was be possible to determine the value of the correlation coefficients, which was applied to a previously built database.

Based on the results, each territorial unit under review was assigned a score, and, based on the score, a ranking was drawn up. The counties in first third of the ranking were be included in zone $A$, which means a reduced level of corruption rates; the second third was be included in Area $B$, which involves an average level of corruption; the rest of the counties with the lowest scores were included in zone $\mathrm{C}$, where the corruption is present at the highest rates.

After establishing these areas, we proceeded to drafting a map that represents the entire scientific endeavour merged. The preparation of a map was chosen, so as information can be understood and interpreted even by people without economic studies.

This study involves combining variables representing three dimensions:

- the average salary and European funds variables represent the economic dimension,

- the number of people with higher education is the educational dimension, and

- the average sentence variable can be included in a social dimension.

\section{Results and discussions}

Following the collection, structuring and processing of information for each analysed variable, a database was obtained and synthesized in Table 1:

\begin{tabular}{|l|r|r|r|r|r|}
\hline Table 1. The Database - Data for the $\mathbf{4 1}$ Counties and the city of Bucharest \\
\hline County & $\begin{array}{c}\text { Percentage } \\
\text { corrupted } \\
\text { persons }\end{array}$ & $\begin{array}{c}\text { Average } \\
\text { wage (\%) }\end{array}$ & $\begin{array}{c}\text { Persons who } \\
\text { graduated a } \\
\text { college (\%) }\end{array}$ & $\begin{array}{c}\text { European funds } \\
\text { (\%) }\end{array}$ & $\begin{array}{c}\text { Average } \\
\text { punishment } \\
\text { (months) }\end{array}$ \\
\hline Alba & 1.05 & 83.37 & 11.24 & 0.99 & 30 \\
\hline Arad & 1.51 & 89.22 & 16.6 & 0.7 & 34.34 \\
\hline Argeş & 2.43 & 104.16 & 12.53 & 3.51 & 33.5 \\
\hline Bacău & 3.21 & 84.16 & 12.75 & 12.9 & 25.83 \\
\hline Bihor & 1.06 & 71.87 & 11.83 & 0.79 & 35.64 \\
\hline Bistrița-Năsăud & 0.31 & 76.02 & 9.05 & 1.14 & 36.18 \\
\hline Botoşani & 0.27 & 76.93 & 6.35 & 1.63 & 37.46 \\
\hline Braşov & 1.04 & 94.28 & 16.35 & 0.9 & 29.52 \\
\hline Brăila & 0.78 & 79.88 & 9.56 & 5.48 & 32.61 \\
\hline Bucureşti & 4.71 & 146.08 & 28.72 & 0.15 & 38.25 \\
\hline Buzău & 0.53 & 82.29 & 8.34 & 3.82 & 23.46 \\
\hline Caraş-Severin & 2.57 & 77.71 & 9.71 & 1.45 & 34.66 \\
\hline Călăraşi & 0.95 & 79.82 & 6.3 & 7.7 & 30.83 \\
\hline Cluj & 1.3 & 106.93 & 17.16 & & \\
\hline
\end{tabular}




\begin{tabular}{|c|c|c|c|c|c|}
\hline County & $\begin{array}{l}\text { Percentage } \\
\text { corrupted } \\
\text { persons }\end{array}$ & $\begin{array}{l}\text { Average } \\
\text { wage (\%) }\end{array}$ & $\begin{array}{l}\text { Persons who } \\
\text { graduated a } \\
\text { college }(\%)\end{array}$ & $\begin{array}{l}\text { European funds } \\
(\%)\end{array}$ & $\begin{array}{c}\text { Average } \\
\text { punishment } \\
\text { (months) }\end{array}$ \\
\hline Constanța & 1.58 & 93.8 & 14.69 & 3.26 & 40.1 \\
\hline Covasna & 0.86 & 74.76 & 8.59 & 2.42 & 30.56 \\
\hline Dâmbovița & 0.81 & 89.4 & 8.51 & 2.26 & 37.48 \\
\hline Dolj & 1.29 & 93.8 & 12.71 & 0.12 & 33.24 \\
\hline Galați & 1.03 & 90.54 & 10.45 & 0.19 & 41.57 \\
\hline Giurgiu & 2.56 & 84.28 & 6.23 & 1.46 & 31.21 \\
\hline Gorj & 1.7 & 101.51 & 11.29 & 0.44 & 40.86 \\
\hline Harghita & 0.55 & 68.8 & 8.54 & 1.52 & 31.12 \\
\hline Hunedoara & 0.53 & 83.01 & 11.97 & 1.39 & 34.77 \\
\hline lalomița & 1.24 & 78.61 & 7.34 & 0.98 & 32.82 \\
\hline laşi & 0.83 & 95.36 & 12.29 & 7.69 & 36.81 \\
\hline llfov & 1.67 & 124.16 & 14.42 & 1.61 & 44.09 \\
\hline Maramureş & 3.36 & 74.1 & 10.37 & 3.01 & 15.01 \\
\hline Mehedinți & 0.23 & 86.87 & 9.72 & 1.27 & 38 \\
\hline Mureş & 0.73 & 87.89 & 10.3 & 1.88 & 24.4 \\
\hline Neamt & 1.51 & 75.66 & 8.59 & 0.71 & 25.49 \\
\hline Olt & 0.53 & 87.17 & 8.25 & 0.26 & 39.74 \\
\hline Prahova & 1.3 & 100.12 & 12.07 & 9.58 & 31.99 \\
\hline Satu Mare & 1.68 & 81.14 & 8.73 & 0.11 & 35.34 \\
\hline Sălaj & 0.09 & 77.11 & 9.31 & 0.99 & 30 \\
\hline Sibiu & 0.55 & 99.82 & 13.38 & 2.99 & 34.86 \\
\hline Suceava & 0.57 & 79.46 & 7.97 & 2.34 & 22.69 \\
\hline Teleorman & 0.26 & 78.67 & 6.81 & 0.01 & 37.8 \\
\hline Timiş & 1.29 & 108.8 & 17 & 0.18 & 38.63 \\
\hline Tulcea & 0.89 & 87.11 & 8.32 & 2.66 & 30.11 \\
\hline Vaslui & 0.66 & 74.28 & 6.46 & 0.74 & 24.54 \\
\hline Vâlcea & 1.35 & 80.66 & 10.54 & 4.25 & 35.66 \\
\hline Vrancea & 1.15 & 75.9 & 8.32 & 1.52 & 27.59 \\
\hline
\end{tabular}

Source: Authors' processing based on the data retrieved from www.romaniacurata.ro and www.gandul.info

After running the regression statistical functions for each independent variable, we obtained four outputs which were summarized in Table 2. In order to differentiate the values of each variable, they were noted as follows:

- 1 - the medium salary variable,

- 2 - the highly educated people variable,

- 3 - the European funds variable,

- 4 - the average sentence variable.
As shown in Table 2, the highly educated people variable displays the strongest correlation with the size of corruption. A very good value is also recorded by the variable average wage, while the lowest correlation in our study lies for the $E U$ funds variable. A first conclusion shows that the highly educated people variable can play a major role in sizing corruption. After processing the database depicted in Table 1, the following ranking resulted, as synthesized in Table 3 . 


\begin{tabular}{|c|c|c|c|}
\hline \multicolumn{2}{|c|}{ Regression Statistics } & \multicolumn{2}{|c|}{ Regression Statistics } \\
\hline Multiple R & 0,473006637 & Multiple R & 0,548305008 \\
\hline R Square & 0,223735279 & R Square & 0,300638382 \\
\hline Adjusted R Square & 0,204328661 & Adjusted R Square & 0,283154342 \\
\hline Standard Error & 0,834797932 & Standard Error & 0,792368746 \\
\hline Observations & 42 & Observations & 42 \\
\hline \multicolumn{2}{|c|}{ Regression Statistics } & \multicolumn{2}{|c|}{ Regression Statistics } \\
\hline Multiple R & 0,229496189 & Multiple R & 0,286993622 \\
\hline R Square & 0,052668501 & R Square & 0,082365339 \\
\hline Adjusted R Square & 0,028985213 & Adjusted R Square & 0,059424473 \\
\hline Standard Error & 0,922204907 & Standard Error & 0,90763523 \\
\hline Observations & 42 & Observations & 42 \\
\hline
\end{tabular}

Source: Ms. Excel processing by the author

\section{Table 3. County ranking based on the estimated level of corruption}

\begin{tabular}{|l|c|l|c|l|c|}
\hline \multicolumn{1}{|c|}{ County (Zone A) } & Score & \multicolumn{1}{c|}{ County (Zone B) } & Score & \multicolumn{1}{c|}{ County (Zone C) } & Score \\
\hline Bucureşti & 44.2834 & Dâmbovița & 25.7604 & Teleorman & 22.757 \\
\hline Ilfov & 35.8225 & Mehedinți & 25.5489 & Călăraşi & 22.6783 \\
\hline Timiş & 32.6375 & Olt & 25.2642 & Bistrița-Năsăud & 22.6572 \\
\hline Cluj & 32.0209 & Hunedoara & 25.1022 & Sălaj & 22.5692 \\
\hline Argeş & 30.0088 & Bacău & 24.9429 & lalomița & 22.5441 \\
\hline Gorj & 29.4875 & Mureş & 24.8642 & Caraş-Severin & 22.4342 \\
\hline Sibiu & 29.378 & Tulcea & 24.6055 & Suceava & 22.1615 \\
\hline Braşov & 29.1739 & Alba & 24.5497 & Botoşani & 22.1556 \\
\hline Prahova & 29.1618 & Vâlcea & 24.3703 & Covasna & 21.9483 \\
\hline Constanța & 28.8706 & Buzău & 24.0711 & Vrancea & 21.8304 \\
\hline laşi & 28.4604 & Satu Mare & 23.6895 & Neamț & 21.6425 \\
\hline Arad & 27.8115 & Giurgiu & 23.3716 & Maramureş & 21.087 \\
\hline Dolj & 27.5457 & Brăila & 23.2197 & Vaslui & 20.6169 \\
\hline Galați & 26.8263 & Bihor & 23.1628 & Harghita & 20.5988 \\
\hline
\end{tabular}

Source: Authors' processing

Bucharest stands the first, having the lowest level of corruption, based on its size. Another barometer supporting this claim might be the greater volume of investors choosing the capital over other areas of the country. Although the general perception of the corruption level in Bucharest is not consistent with the results of the current research, the explanation may come from the fact that the losses due to corruption are much higher than in any other county, which attracts media attention, the corruption cases in Bucharest getting a lot of publicity. Corruption is a very complex phenomenon that cannot be assessed solely through an economic perspective.

Corruption also entails a social dimension, behaviour of the masses, which can be influenced or shaped by various factors, such as television, newspapers etc. The strongest variable in this study was the amount of highly educated people, which in Bucharest is at the highest level $(28.72 \%)$, while Vaslui County, which is the penultimate position in the corruption ranking, also lies last on the share of highly educated people (6.46\%). Vaslui also recorded very low scores for the average 
wage, which represents only $74.28 \%$ of the national average wage. The variable that refers to attracting European funds does not have a great impact on the scale of corruption, however Vaslui draws only $0.74 \%$ of the total absorbed EU funds at national level in 2014. A county comparable to Vaslui as the population number is Sibiu, which manages to attract over 4 times more European funds than Vaslui County. Sibiu also has twice as many highly educated people, as compared to Vaslui.

From the study results, it may be concluded that in Romania corruption is closely linked to the education level. Romanians do not seem to realize the catastrophic effects of this phenomenon, which makes or country quite vulnerable, from the economic point of view. Analysing the counties in zone $\mathrm{A}$, we find that the maximum interval, the one between the score of Ilfov (35.8225) and Galati (26.8263) is almost nine points (8.9962), while for the zones $B$ and $C$, the amplitude is less than two points. This means that the areas $B$ and $C$ do not have very high volatility in terms of differences for the estimated level of corruption, between the first and the last county, as recorded in area A, between the district of Ilfov and Galați County.

Except from Bucharest, which presents certain peculiarities, we find that the average score for the zone $A$ is 29.7850 points, compared to 24.4659 as it is in zone $\mathrm{B}$, or 21.9772 as is recorded in zone $\mathrm{C}$. When making a ranking of the first three counties in Romania, it includes Ilfov, Timiş and Cluj. It appears that Iffov County is detached from counties in positions two and three by more than three points, while the difference between Timiş and Cluj score is under 0.7 points. Score difference between the last county in zone A (Galati) and the first county in zone $B$ (Dâmbovița) is insignificant.

The amplitude of zone $B$ is 2.5976 points, that is the difference between Dâmbovița County score (25.7604) and Bihor County score (23.1628). Zone B variations in the score are significantly lower than in zone $A$ for both variations of the score between the first and second position and for the last two counties at the end of the chart.

The last three positions belong to Maramureş (21.6169), Vaslui (20.59880) and Harghita (20.5988). The amplitude of zone $C$ is 2.1582 points, resulting from the difference between the score of Teleorman County (22.757) and Harghita County (20.5988). The maximum amplitude level among the 41 counties is 15.2237 points, and if we include Bucharest, the maximum amplitude reaches 23.6846 points. The average score across all counties is 25.3026 points and after the inclusion of Bucharest, the average score reaches 25.7545 points. Following this analysis, data were summarized and presented in the form of a map, as shown in Figure 1.

\section{Figure 1. The map of corruption, by county}

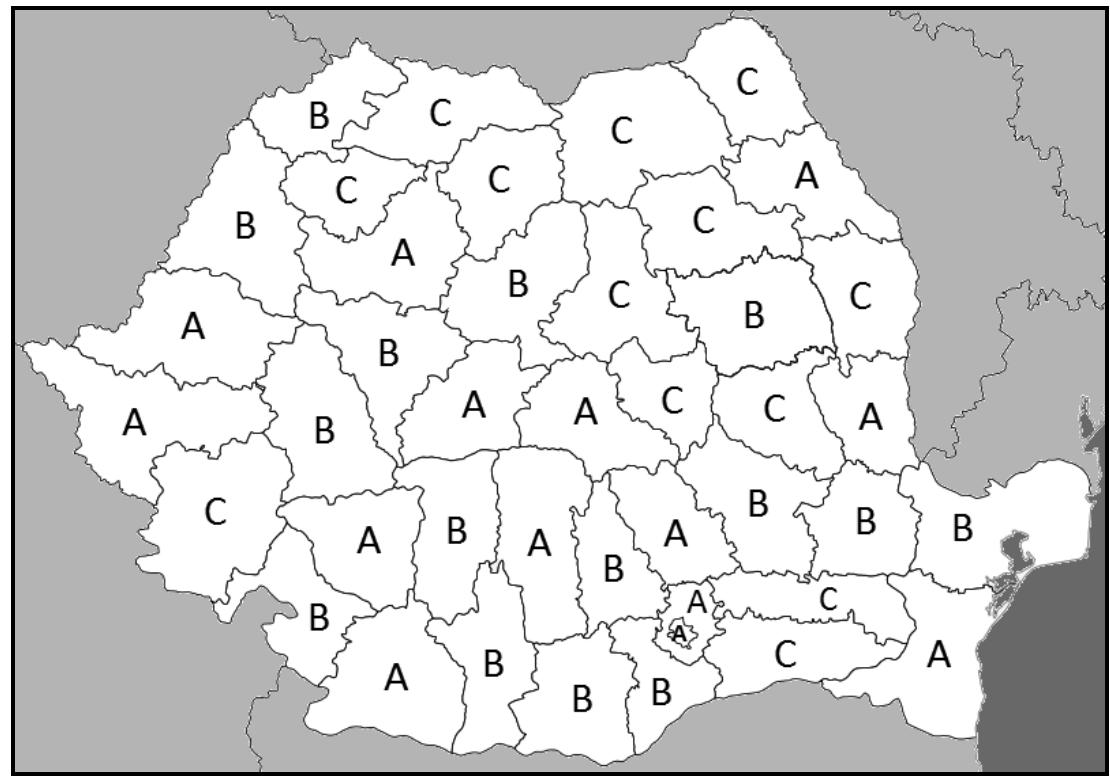

Source: Authors' processing, 2016

No. $6(138) / 2016$ 
As depicted in Figure 1, the counties of zone $A$ are the richest in Romania. All major regions of the country (Muntenia, Transylvania and Moldova) are included in zone $B$ and zone $C$ mainly encloses counties in Moldova, with a few exceptions from Transylvania and Muntenia.

\section{Bonclusions}

One of the main influence factors for the size of corruption is the level of highly educated people in the total population. In Moldova, with a few exceptions, the share of people with higher education is below the national average.

Another factor of influence is the average level of the salary, for each of the analysed counties. Unfortunately, lowest values are recorded in the counties having fairly high levels of corruption. Thus, for counties like Harghita, Vaslui, Neamt, Covasna the average salary is about 25\% lower than the national average.

The economic component can be held responsible for the size of corruption in Romania, which brings many disadvantages internationally. The fact that many people do not realize the negative effects of corruption may be due to an under-financing of the education system and also to the lack of interest from senior government officials to inform the population.

Poverty in the least developed counties may represent a favourable environment for increased probability of manifesting a more pronounced tolerable behaviour to corruption.

The variable that refers to the share of European funds absorbed by each county aimed to assess the interest of local authorities to bring more wealth among the population through investments that could raise living standards and indirectly create prerequisites of a corruption phenomenon located at lower rates. On the other hand, attracting European funds requires a higher degree of transparency in the allocation of funds to various destinations, which could encourage justice institutions' efforts to reduce the size of corruption.

Another variable in determining the size of corruption is the length of the sentence for corruption charges. The average duration for which a person is convicted for corruption charge is 32.92 months, very close to the value recorded for Bucharest, which is 32.61 months. In other words, a person who commits acts of corruption and is sentenced will be released, on average, in less than 3 years, without considering early release (for good behaviour, written books, various health problems, old age etc.). In zone $A$, the average length of detention is 36.49 months, in zone $B$, the average length of detention is 33.21 months, and in the zone $C$, the average length of detention is 29.07 months.

An equally alarming situation is found in the case of the EU funds absorption. Counties in zone $\mathrm{C}$ barely manage to attract $21.44 \%$ of the total European funds absorption in 2014. In the counties from zone $B$, the situation is more balanced in the sense that they attract $33.48 \%$ of the total European funds. It is very surprising that almost half $(45.08 \%)$ of the European funds absorption by Romania in 2014 are targeted only to the 14 territorial units of zone $A$.

In a future research we intend to perform a detailed analysis, focused on the economic potential and the standard of living in each county (GDP/capita, index of prices growth, purchasing power, etc.). The results will be compared to the estimation of the size of corruption in the current research.

\section{REFERENCES}

1. Beşliu, D. (2015), Securitatea frontierelor europene: Actualităti şi perspective, Revista de investigare a criminalitățtii, vol. 8, no. 2, pp. 185-197.

2. Dang, V. (2009), Institutional determinants of investment in transition economies, Economics and Finance Working Paper Series, Brunel University West London: Working Paper No. 09-33 [online] Available at: https://www.brunel.ac.uk/_data/ assets/pdf_file/0019/82126/0933.pdf [Accessed on May 11, 2016].
3. Diaconu, N. ( 2012), Testul de integritate. Între necesitate şi legalitate, Revista de investigare a criminalității, vol. 5, no. 2, pp. 10-14.

4. Dispersia fondurilor europene, [online] Available at: http://storage0.dms.mpinteractiv.ro/ media/1/186/31966/13746904/11/judete-fonduri.jpg [Accessed on February 15, 2016].

5. Graeff, P. şi Svendsen, G.T. (2013), Trust and corruption: The influence of positive and negative 
social capital on the economic development in the European Union. Quality \& Quantity, International Journal of Methodology, vol. 47, no. 5, pp. 28292846.

6. Harta coruptiei județene, [online] Available at: http://www.romaniacurata.ro/harta-coruptiei/ [Accessed on January 12, 2016].

7. Harta salariilor pe regiuni, [online] Available at:

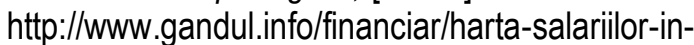
2015-cu-cat-vor-creste-lefurile-romanilor-dinfiecare-judet-13743567 [Accessed on January 2, 2016].

8. Kaditi, E.A. (2013), Foreign Investments and Institutional Convergence in South-eastern Europe, International Economic Journal, vol. 27, no. 1, pp. 109-126, DOI: http://dx.doi.org/10.1080/10168737.2012.682076.

9. Krkoska, L. and Robeck, K. (2008), Business environment and enterprise behaviour in East Germany compared to West Germany and Central Europe, Journal of Comparative Economics, vol.
36, no. 4, pp. 568-583, DOI:

http://dx.doi.org/10.1016/j.jce.2008.03.001.

10. Li, Y. and Zahra, S. (2012), Formal institutions, culture, and venture capital activity: A crosscountry analysis, Journal of Business Venturing, vol. 27, no. 1, pp. 95-111, DOI: http://dx.doi.org/10.1016/j.jbusvent.2010.06.003 .

11. Marinescu, C. and Jora, O.D. (2013), Elemente de „economie instituțională” a corupției. Afaceri şi dezvoltare în România, între formal şi informal, Amfiteatru Economic, vol. 15, no. 7, pp. 426-438.

12. Preda, E. (2015), Dezinformarea şi manipularea factori agravanți în lupta corupției în estul Europei, Revista de investigare a criminalității, vol. 1, special no./2015, pp. 295-301.

13. Raport de cercetare ARACIP, [online] Available at : http://www.insse.ro/cms/ro/content/ statisticaeducatiei [Accessed on January 14, 2016].

14. Zelekha, Y. and Sharabi, E. (2012), Corruption, institutions and trade, Economics of Governance, vol. 13, no. 2, pp. 169-192. 